Отже, за результатами нашого дослідження встановлено, що для хворих на ХОЗЛ із ЦД типу 2 характерним $\epsilon$ більш торпідний клінічний перебіг (виражений кашель та задишка, аскультативна картина в легенях, вища частота госпіталізацій 3 приводу загострення захворювання). Показники ФЗД $\left(\mathrm{OФB}_{1}\right.$, ФЖЕЛ, ПОШвид, СОШ25-75) були також нижчими у даного контингенту хворих на тлі змін складу тіла (вірогідно вищий IMT, відсоток жирової маси, рівень вісцерального жиру та низької м'язової маси). Відстань, яку хворі на ХОЗЛ із ЦД типу 2 проходили за 6 хвилин, була нижчою порівняно із першою групою пацієнтів.
Інтегральний індекс BODE також був нижчим у першій групі пацієнтів.

Висновки. У хворих на ХОЗЛ із ЦД типу 2 спостерігається тяжчий клінічний перебіг, нижчі показники ФЗД, зміна складу тіла (вищий IMT, відсоток жирової маси, рівень вісцерального жиру та зниження м'язової маси), зниження толерантності до фізичного навантаження. Для даного контингенту хворих $\epsilon$ характерним тяжчий перебіг і відповідно прогноз захворювання порівняно із групою хворих на ХОЗЛ.

Горох B.B.

\title{
Оцінка хворими на хвороби крові та кровотворних органів доступності та якості первинної медичної допомоги
}

Сумський державний університет, м. Суми, Україна

Мета - дослідити та проаналізувати рівень доступності та якість первинної медичної допомоги для населення Сумської області із хворобами крові та кровотворних органів.

Матеріали та методи. За спеціально розробленою анкетою було опитано 200 жителів області хворих на хвороби крові та кровотворних органів. При виконанні роботи використано соціологічний та медикостатистичний методи. При проведенні дослідження були збережені конфіденційні дані про респондентів.

Результати. Першим кроком дослідження було вивчення частоти звертання опитаних за медичною допомогою до сімейних лікарів. Отримані результати наведено в табл. 1.

Аналіз отриманих даних даних вказує на те, що за медичною допомогою до лікарів загальної практики -

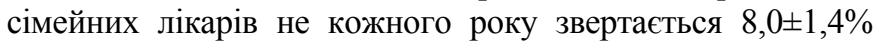
респондентів, $44,0 \pm 2,5 \%$ із них звертається до 5 разів на рік, a $31,5 \pm 2,3 \%$ опитаних звертається більше 5 разів на рік.
Таблиця 1. Частота звертання жителів Сумської області із хворобами крові та кровотворних органів за медичною допомогою до лікаря загальної практики-сімейного лікаря

\begin{tabular}{|l|c|c|}
\hline \multicolumn{1}{|c|}{ Показник } & Абс. & \% \pm \\
\hline Щорічно & 33 & $16,3 \pm 1,8$ \\
\hline Не кожного року & 16 & $8,0 \pm 1,4$ \\
\hline До 5 разів на рік & 88 & $44,0 \pm 2,5$ \\
\hline Більше 5 разів на рік & 63 & $31,5 \pm 2,3$ \\
\hline
\end{tabular}

При цьому в ході дослідження отримані дані, що тільки $52,0 \pm 2,5 \%$ опитаних, які мають хвороби крові та кровотворних органів знаходиться під диспансерним наглядом у лікаря загальної практики-сімейного лікаря.

Далі вивчалося та аналізувалося питання щодо оцінки доступності та якості респондентами первинної медико-санітарної допомоги. Результати дослідження наведено в табл. 2.

Таблиця 2. Оцінка населенням Сумської області із хворобами крові та кровотворних органів доступності та якості первинної медико-санітарної допомоги

\begin{tabular}{|c|c|c|}
\hline Показник & Абс. & $\% \pm$ \\
\hline \multicolumn{3}{|c|}{ Територіальна доступність первинної медичної допомоги } \\
\hline Доступна & 131 & $65,5 \pm 2,4$ \\
\hline Скоріше доступна ніж недоступна & 39 & $19,5 \pm 2,0$ \\
\hline Скоріше недоступна ніж доступна & 26 & $13,0 \pm 1,7$ \\
\hline Недоступна & 4 & $2,0 \pm 0,7$ \\
\hline
\end{tabular}




\begin{tabular}{|l|c|c|}
\hline \multicolumn{3}{c}{ Економічна доступність первинної медичної допомоги } \\
\hline Доступна & 40 & $20,0 \pm 2,0$ \\
\hline Скоріше доступна ніж недоступна & 74 & $37,0 \pm 2,4$ \\
\hline Скоріше недоступна ніж доступна & 47 & $23,5 \pm 2,1$ \\
\hline Недоступна & 39 & $19,5 \pm 2,0$ \\
\hline & Якість первинної медичної допомоги & $23,5 \pm 2,1$ \\
\hline Якісна & 47 & $44,5 \pm 2,5$ \\
\hline Скоріше якісна ніж неякісна & 89 & $19,5 \pm 2,0$ \\
\hline Скоріше неякісна ніж якісна & 39 & $12,5 \pm 1,7$ \\
\hline Не якісна & 25 & \\
\hline
\end{tabular}

Аналіз отриманих даних вказує на те, що 85,0 $1,8 \%$ опитаних оцінили медичну допомогу у сімейних лікарів доступною територіально та $57,0 \pm 2,5 \%$ доступною економічно. В цілому позитивно оцінили якість первинної медичної допомоги $68,8 \pm 2,4 \%$ респондентів. Негативним $\epsilon$ те, що $15,0 \pm 1,8 \%$ респондентів вважають первинну медичну допомогу недоступною територіально та малодоступною, а економічно $19,5 \pm 2,0 \%$ оцінили їх недоступною та 23,5 $\pm 2,1 \%$ - малодоступною. При цьому $32,0 \pm 2,3 \%$ респондентів вказали на низьку якість первинної медико-санітарної допомоги.
Висновки. Результати проведеного соціологічного дослідження вказали на недостатній рівень доступності та якості первинної медичної допомоги для жителів Сумської області, які хворі на хвороби крові та кровотворних органів, що вимагає в умовах реформування галузі охорони здоров'я прийнятті відповідних управлінських рішень та проведення організаційних заходів в системі охорони здоров'я регіону.

Прокопів М.М., Слабкий Г.О.

\title{
Концептуальні підходи до надання медичної допомоги хворим на цереброваскулярні хвороби на первинному рівні в умовах мегаполісу
}

\author{
Національний медичний університет імені О.О. Богомольця, м. Київ, Україна
} ДВНЗ «Ужгородський національний університет», м. Ужгород, Україна

Мета - розробити концептуальні підходи до надання медичної допомоги хворим на цереброваскулярні хвороби на первинному рівні.

Матеріали та методи. При проведенні дослідження використано чинні законодавчі акти України 3 питань організації діяльності первинної медикосанітарної допомоги населенню та міжнародні рекомендації 3 організації медичної допомоги при цереброваскулярних хворобах та церебральних інсультах, результати особистих попередніх досліджень. При виконанні роботи використано методи контент-аналізу та структурно-логічного аналізу. Дослідження проводилося на базі системи охорони здоров'я м. Києва.

Результати. В м. Києві на цереброваскулярні хвороби страждає 147136 осіб дорослого населення, що становить 627,78 на 10 тис. відповідного населення, а вперше захворіло 15995 осіб, що становить 6878 на 10 тис. дорослого населення міста. Із них під диспансерним наглядом знаходиться $36,17 \%$. На цереброваскулярні хвороби з гіпертонією страждає 84576 осіб дорослого населення, що становить 360,86 на 10 тис. відповідного населення, а вперше захворіло 10194 осіб, що становить 43,49 на 10 тис. дорослого населення міста. Із них під диспансерним наглядом знаходиться $340,8 \%$. В 2018 році на транзіторні церебральні ішемічні напади та спорідненні синдроми захворіло 629 жителів міста, що склало 2,68 на 10 тис. дорослого населення. Всі дані жителі міста під диспансерним наглядом не знаходяться і складають групу високого ризику розвитку церебральних інсультів. На всі форми церебральних інсультів захворіло 3376 осіб або 14,39 осіб на 10 тис. дорослого населення. Із них під диспансерним наглядом лікарів знаходиться 76,25\%. При цьому медична допомога населенню 3 вказаною патологією до проведення реформи надавалася лікаряминеврологами поліклінік. В умовах реформування системи надання медичної допомоги, коли сімейний лікар визначає медичний маршрут пацієнта, здійснює динамічний нагляд за здоров'я прикріпленого населення i без його 